\title{
The Value and Size Effect - Are There Firm-Specific-Risks in China's Domestic Stock Markets?
}

\author{
Hong $\mathrm{Wu}$ \\ Department of Economics, University of St. Thomas \\ 2115 Summit Avenue, St. Paul, MN 55105, USA \\ Tel: 1-651-962-5667 E-mail: hwu2@stthomas.edu
}

Received: November 10, 2010

Accepted: December 8, 2010

doi:10.5539/ijef.v3n3p26

\begin{abstract}
The Fama-French three-factor asset pricing formula is applied to the Chinese A-share markets: Shanghai and Shenzhen Stock Exchanges (SSE and SZSE). The benchmark explanatory returns - value and size premiums are constructed and adopted in the cross-sectional regressions. Market beta has no explanatory power. There are some evidences of the value effect only for the SSE. No significant size effect was found. The results are robust with or without the influences of the exchange rate reform and the recent financial crisis. The model works better in general for the SSE than for the SZSE, regardless of the specifications. There may well be different fundamental forces in the two markets. The pricing regularities pervasive in most equity markets do not explain the Chinese markets sufficiently well.
\end{abstract}

Keywords: Cross-Sectional Expected Returns, The Chinese A-share Stock Markets, Market Beta, Value Premium, Size Premium

\section{Introduction}

Voluminous empirical contradictions of the asset pricing model of Sharpe (1964), Lintner (1965), and Black (1972) have emerged during the past two three decades - market $\beta s$ fail to describe the cross-section of expected returns. Banz (1981) documents a strong negative relation between average return and firm size. Chan, Hamao, and Lakonishok (1991) find that book-to-market (B/M) ratio is also a powerful variable for explaining average returns on Japanese stocks. Fama and French (1992) confirm that "two easily measured variables, size and book-to-market equity, combine to capture the cross-sectional variation in average returns associated with market $\beta$." Small firms outperform big firms and value stocks (with high B/M ratio) outperform growth stocks (with low B/M ratio). Fama and French (1998) show that the value premium is indeed pervasive in thirteen major markets and sixteen emerging markets. (Note 1) Barry et al. (2002) claim that the size and the B/M effects are robust across thirty-five emerging markets.

China is one of the fastest growing economies in the world and the Chinese government is committed to continuous privatization and liberalization through its stock markets toward a more market-oriented economy. This paper examines whether a much-cited and widely accepted multifactor asset pricing formula — market beta, value and size effects, explains the cross-sectional variations in expected stock returns in China.

China launched two stock exchanges - the Shanghai Stock Exchange (SSE) in 1990 and the Shenzhen Stock Exchange (SZSE) in 1991 and both have grown rapidly since their inception (see Table 1). In May 2010, there are 879 companies listed on the Shanghai Stock Exchange with 1,731.2 billion shares outstanding. The total market capitalization is 14,997.1 billion Renminbi (RMB) or US $\$ 2,215$ billion at the exchange rate of $\$ 1=6.77$ Chinese Yuan. The average P/E ratio is 19.90. On the Shenzhen Stock Exchange, there are 984 listed companies with 445.5 billion shares outstanding. The total market capitalization is 5,967 billion RMB (US\$ 881 billion). The average P/E ratio is 33.72. (Note 2)

Two classes of shares are traded on domestic stock exchanges: A and B shares. A-shares are quoted and traded in Renminbi, and currently only mainlanders and selected foreign institutional investors are allowed to trade A-shares. B-shares are quoted in Renminbi but traded in foreign currencies (US\$ in SSE and HK\$ in SZSE). In the past, only foreigners were allowed to trade B shares. Starting from March 2001, mainlanders can trade B-shares as well. However, they must trade with legal foreign currency accounts. A-shares and B-shares are equivalent in terms of voting power and claims on earnings and assets. B-shares account for a very small part of the total market capitalization - about $0.47 \%$ for SSE and 2.39\% for SZSE (May 2010); hence this paper focuses on explaining the pricing of A-shares only. 
A-shares have a unique capital structure including state shares, legal entity shares, and public shares. State shares are held by the government and legal entity shares are held by state-owned or partially state-owned enterprises or institutions. Both state and legal entity shares cannot be traded on the stock exchanges. Public shares are held by ordinary individual investors that are freely tradable. The proportion of tradable shares has been increasing; in May $2010,73 \%$ of total shares were tradable on SSE and $66 \%$ of total shares were tradable on SZSE.

In general perception, the Chinese stock markets are not considered as being effective in promoting corporate efficiency for that share prices are not correlated with corporate results; standards of disclosure and corporate governance fall short of global norms due to heavy government regulation; and the market is dominated by small retail investors who are concerned primarily with short-term trading profits and speculation. How might these market imperfections have affected the expected stock returns? Is asset pricing in China irrational? Can we find the empirical regularities there?

The remainder of this paper is organized as follows: Section 2 highlights the recent research on China's stock markets. Section 3 describes the methodology and the data. Section 4 presents the empirical results. Section 5 concludes.

\section{Literature Review}

The remarkable growth and the increasingly critical role have driven more and more researches on various aspects of the Chinese stock markets. (Note 3)

Cheng (2009) provides a systematic analysis of the development of the Chinese stock market in the first 10 years and discusses the major problems that should be addressed in order to build a mature stock market in China to support sustainable economic growth.

Regarding market efficiency, Liu, Song, and Romilly (1997) show that the Shanghai and the Shenzhen market are efficient individually but the two markets are inefficient collectively. Charles and Darné (2009) find that B-shares are significantly inefficient and A-shares seem more efficient. Wang, Liu, and Gu (2009) find that Shenzhen stock market was becoming more and more efficient. Hung (2009) show that increased liquidity and maturity accompanying deregulation and liberalization improve market efficiency. Not surprisingly to the authors, Lim and Brooks (2009) reject the market efficiency hypothesis given the fact that investors in the Chinese stock markets trade like noise traders, who purely speculate and treat the market like a casino.

The special attributes of the Chinese stock markets are worth investigating. Qi, Wu, and Zhang (2000) examine how shareholding structure influences corporate performance of listed firms on the SSE. They find that firm performance is negatively related to the proportion of state shares. Chen, Firth, Xin, and Xu (2008) find that ownership transfers from state entities to private entities enhance corporate profitability and efficiency. Zhang, Sun, and Wang (2008) show that political consideration of the government can be a critical force that drives the stock market anomaly.

The calendar effect is another area of interest. Chen, Kwok, and Rui (2001) find negative returns on Tuesday after January 1, 1995. This Tuesday anomaly disappears after taking the non-normality distribution and spillover from other countries into account. The finding suggests that this day-of-the-week regularity in China may be due to the spillover from the Americas. Cai, Li, and Qi (2006) find significant day-of-the-week effect for A shares and B shares traded on the Shanghai and Shenzhen stock exchanges - average Monday returns from A-share indexes are significantly negative during the third and fourth weeks, as in the U.S. market. Average Tuesday returns on most of the A-share and B-share indexes are negative during the second week of the month. Oqunc, Nippani, and Washer (2009) show that the Shanghai A index is prone to higher volatility and with some January and Weekend Effects.

Much attention has been given to the relative pricing of A-shares versus B-shares-B-shares trade at a substantial discount relative to A-shares. Fung, Lee, and Leung (2000) show that the two-tier markets are loosely related which reflect different fundamental forces. Fernald and Rogers (2002) estimate how various company characteristics affect the relative price paid by foreigners and domestic residents. Zhang and Zhao (2004) argue that the valuation differential is attributable to the different sets of investment opportunities available to domestic versus foreign investors and their risk tolerance. Foreign investors would require a higher rate of return to adjust for the country-specific risk related to the Chinese stock market. The country risk of China can be decomposed into political risk, exchange rate risk, interest rate risk and market risk. Chan, Menkveld, and Yang (2008) document that information asymmetry explain a significant portion of cross-sectional variation in B-share discounts. Lee, Rui, and $\mathrm{Wu}(2008)$ find that the B-share discounts declined substantially after the lifting of restrictions on foreign ownership in China. Ahlgren, Sjo, and Zhang (2009) find that the A-share premia are nonstationary, and that the A- and B-share prices are not cointegrated up till January 2001. After February 2001, when domestic investors were allowed to trade B shares, the A-share premia become stationary and the A- and B-share prices cointegrated. This 
suggests that the relaxation of the investment restrictions decreased the segmentation between the A- and B-share markets in China.

In relation to global investors and markets, Tunaru, Fabozzi, and Wu (2006) show that China's stock market contributes differently and substantially to the diversification benefits of international investment portfolios. Fan, $\mathrm{Lu}$ and Wang (2009) document that there has been a significant trend of long-term co-movement between the China and the international stock markets since 1999; in short term, the stock market in China has been impacted directly or indirectly by the international main stock markets. Lai and Tseng (2010) find that the Chinese stock market has been not only a hedge but also a safe haven for the G7 stock markets. Schuppli and Bohl (2010) conclude that foreign institutions help stabilize the Chinese stock markets and contribute to market efficiency.

Concerning the pricing behavior, Xiao (2006) finds that stock valuations in China deviate significantly from underlying firm-level fundamentals. Specifically, the worse firms perform, the higher are their valuation ratios. This suggests that China's stock market development might produce an inefficient resource allocation and cause detrimental effects on the real economy.

De Bondt, Peltonen, and Santabarbara (2010) assess the ability of three conventional fundamentals: corporate earnings, the risk-free interest rate and a proxy for the equity risk premium in explaining the stock price movements in the Shanghai market. They find that the fundamentals considered in the dynamic present value model fits reasonably well to China's stock prices and the conclusion is robust across various proxies for the equity risk premium. Policy actions such as deposit rate changes, equity market reforms or excess liquidity are potential drivers of the stock price misalignments. Their empirical methodology models the long-run relationship between stock price and the fundamentals.

As one may have noticed, little is known from the extant literature, about the cross-sectional pricing mechanism of the Chinese A-shares. Narayan and Zheng (2010) consider the role of the market liquidity risk factor. The explanatory power of the Fama-French three-factor model, the main task of this study, has also been the focus of several related papers. According to Drew, Naughton, and Veeraraghavan (2003), small and growth firms generate superior returns than big and value firms. Therefore, they report that the value effect is not as pervasive as was found for the US portfolios and other international markets. However, they only run the one-stage time series regressions using mimic portfolios based on size and book-to-market equity. No cross-sectional pricing analysis was conducted.

Rutledge, Zhang, and Karim (2008) examine the relationship between firm size and excess stock returns in the Chinese stock markets in both a bull and bear market. Their results indicate that a size effect exists over the 6-year period from 1998 to 2003. Moreover, small firms are found to have a stronger reaction to the direction of the market than large firms. Small firms have significantly greater positive excess returns than large firms during the bull market and significantly greater negative returns during the bear market period. The value effect was not examined.

Eun and Huang (2007) document that the market risk is not priced; firm size and the book-to-market ratio are systematically related to stock returns. Nevertheless, the high correlations among their explanatory variables - market beta, natural logarithms of market value and natural logarithms of book-to-market ratio of individual firms, make the slopes in the regressions hard to interpret.

By contrast, in this paper, I construct the benchmark explanatory returns following Fama and French (1993) - the value premium (the difference between the average returns of high book-to-market ratio companies and low book-to-market ratio companies, H-L) and the size premium (the difference between the average returns of small firms and big firms, S-B) - for the Chinese A-share markets and then test whether these hypothesized firm-specific-risks (along with market beta) are on average priced. The risk loadings on all three factors (market, value and size) are estimated simultaneously and the estimated betas are then used to explain the cross-sectional return variations. No such attempt was made before. Section 3 provides a detailed explanation of my methodology and data.

\section{Methodology and Data}

\subsection{Methodology}

The multifactor model in question is given by equation (1).

$$
\mathrm{R}-\mathrm{F}=\alpha+\beta_{1}[\mathrm{M}-\mathrm{F}]+\beta_{2}[\mathrm{H}-\mathrm{L}]+\beta_{3}[\mathrm{~S}-\mathrm{B}]+\varepsilon,
$$

$\mathrm{R}$ is the return of an individual stock. $\mathrm{F}$ is the risk free interest rate and $\mathrm{M}$ is the return on a market portfolio. $\mathrm{H}$ (high book-to-market ratio) represents the average return of firms whose $\mathrm{B} / \mathrm{M}$ is among the highest $30 \%$ of all companies and L (low book-to-market ratio) represents the average return of firms whose B/M is among the lowest $30 \%$. S 
(small firm) represents the average return of firms whose market value is among the lowest $30 \%$ of all companies and B (big firm) represents the average return of firms whose market value is among the highest $30 \%$. H-L, the value premium and S-B, the size premium, offer the firm-specific-risks that are to be tested. All returns are monthly.

Each month, the value (H-L) and the size (S-B) premiums are obtained by sorting all firms by their book-to-market ratios and market values and calculate the corresponding differences in average returns of selected firms as defined in the last paragraph. The month-by-month value and size premiums are then recorded and adopted as the additional explanatory factors.

I employ the Fama and MacBeth (1973) two-stage regression methodology. The first pass is the time series regression of equation (1) to get the estimated risk loadings $-\widehat{\beta_{1}}, \widehat{\beta_{2}}$, and $\widehat{\beta_{3}}$ for each individual stock. The betas are constant over the sample period. In the second pass, the estimated betas are used to explain the cross-sectional stock returns month by month (equation (2)). This generates a series of second-pass coefficients $\widehat{a_{0}}, \widehat{a_{1}}, \widehat{a_{2}}$, and $\widehat{a_{3}}$.

$$
\mathrm{R}-\mathrm{F}=\mathrm{a}_{0}+\mathrm{a}_{1} \widehat{\beta_{1}}+\mathrm{a}_{2} \widehat{\widehat{\beta_{2}}}+\mathrm{a}_{3} \widehat{\widehat{\beta_{3}}}+\mathrm{e},
$$

The intercept $\mathrm{a}_{0}$ measures the pricing error, the portion of the expected return not captured by the model. The slopes $\mathrm{a}_{1}, \mathrm{a}_{2}$, and $\mathrm{a}_{3}$ are the hypothesized risk factors - the market beta, the value premium, and the size premium respectively. If the pricing formula (equation (1)) explains the data well, the mean of the second pass intercepts $\left(\widehat{a_{0}}\right)$ should be insignificantly different from zero, indicating no or little pricing error. The means of $\widehat{a_{1}}, \widehat{a_{2}}$, and $\widehat{a_{3}}$ should be significant. In addition, $\widehat{\mathrm{a}_{1}}$ should be insignificantly different from the actual average excess return on the market portfolio $(\mathrm{M}-\mathrm{F})$; $\widehat{\mathrm{a}_{2}}$ should be insignificantly different from the actual average value premium and $\widehat{\mathrm{a}_{3}}$ should be insignificantly different from the actual average size premium.

Significance here is based on the t-statistic, dividing each coefficient mean by its standard error. The problem of generated regressors in the second stage can be resolved by using Shanken (1992) corrections.

\subsection{Data Description}

\section{All my data come from "Taiwan Economic Journal's China Database". (Note 4)}

Individual stock prices are adjusted for dividends and rights offerings. Three-month fixed deposits rates are used as the risk free interest rate F. A-share market index is chosen as the market proxy M. Firm size is measured by the market value of A-shares which is the number of A-shares outstanding (including state, legal entity, and public shares) multiplied by the market price per share. As the current market value of A-shares is not readily available, previous month-end market value is matched with current month's return.

$\mathrm{B} / \mathrm{M}$ is defined as the book value of A-shares divided by the market value of A-shares. Book value of A-shares is computed as the book value of common equity multiplied by the proportion of A-shares to the total number of shares. The authority requires the listed firms to release their previous year's annual report before April 30 . To avoid look-ahead bias, the accounting data from calendar year $\mathrm{t}-1$ are used to match the returns from May of year $\mathrm{t}$ to April of year $\mathrm{t}+1$.

Only companies with 60 months or more observations are included in my sample to ensure sufficient data points for beta estimation and second pass regression. This results in 744 companies on the SSE and 468 companies on the SZSE. In the second-pass, there are 203 months from June 1992 to April 2009 for SSE and 159 months from February 1996 to April 2009 for SZSE. The number of companies in each month varies.

As shown in Table 2, both the SSE and the SZSE markets are highly volatile, the range of the SSE excess market return is $127.7 \%$ and the range of the SZSE excess market return is $64.5 \%$. The market portfolio mean return is positive (SSE: $0.09 \%$; SZSE: $1.1 \%$ ), however, contradicting to most equity markets, not significant. Noticeably, there are significant value premiums $($ SSE: $t=8.60$; SZSE: $t=8.84)$ and size premiums (SSE: $t=6.28$; SZSE: $\mathrm{t}=5.28$ ) in both markets. Moreover, the magnitude of the premium, on a monthly basis (value: $2.59 \%$ and $2.13 \%$; size: $2.23 \%$ and $1.80 \%$ ), is large (Note 5). The correlation coefficients among the three explanatory factors are all low except between H-L and S-B in SSE (see Table 3).

\section{Results}

\subsection{Main Results - the Whole Period}

Descriptive statistics of betas estimated from the first-pass time-series regressions are provided in Table 4 . The betas exhibit similar patterns in the two markets.

Table 5 presents the second-pass month-by-month cross-sectional regression results. The asset pricing models (with various combinations of the hypothesized risk factors) seem to work better in explaining the expected returns of stocks listed on the SSE. The means of the intercepts are insignificantly different from zero for all specifications, 
indicating zero pricing errors. The market beta alone, the market beta and the size effect, produce high pricing errors in magnitude. Adding the value factor helps reduce the size of the intercept.

For the SZSE, the market beta alone produces a significantly different from zero intercept at the $5 \%$ level. Among the rest of the model specifications, three intercepts are significantly different from zero at the $10 \%$ level; three intercepts are not significantly different from zero. Note that the statistically insignificant intercepts are economically significant $(0.83 \%, 1.33 \%$, and $1.21 \%)$. All intercepts from the SZSE are both statistically and economically higher than those from the SSE. This may suggest different fundamental forces in the two markets.

Regarding the three risk factors, the market beta is always insignificant, alone or with the value or/and the size effect. This is not surprising given that no systematic reward on the market portfolio was found from the original data. Despite the fact that value firms outperform growth firms and small firms outperform large firms indicated by the monthly raw returns (Table 2), no significant value premium or size premium are observed in the pricing mechanism from the SZSE results. The value premiums are positive yet insignificant. All the size premiums have the wrong negative sign; two of them are significant at the $10 \%$ level. The data suggest that big firms performed well. This is interesting because in China, large corporations are mostly state-owned enterprises with monopoly power or other privileges. The special institutional setting of the Chinese economy may attribute to the return anomaly.

The estimated value and size premiums from the SSE results are all positive. In addition, two value premiums are significant at the $10 \%$ level, one from a two-factor model (market beta and value) and one from the three-factor model (market beta, value, and size). There is no evidence of a significant size effect. The adjusted $\mathrm{R}^{2}$ are low. The highest adjusted $\mathrm{R}^{2}$ is associated with the model where all three factors are present for both markets.

It is worth noting that the results (Table 5) from different model specifications are pretty close, suggesting that some of the risks are redundant. No single factor stands out as significant except some evidences of the value premium from the SSE. The estimated mean slopes $\left(\widehat{\mathrm{a}_{1}}, \widehat{\mathrm{a}_{2}}\right.$, and $\left.\widehat{\mathrm{a}_{3}}\right)$ are different from, mostly lower than, the actual means.

\subsection{Robustness Test-the Sub Period}

During the period 2005-2009 China has undergone a major exchange rate policy reform (Note 6), the extremely volatile stock market (Note 7) and the global financial crisis and recession. To check the impact of these major events and test the robustness of my findings, I run the same set of regressions on a sub period deleting all months after June 2005 from the original sample. The sub period for the SSE is from June 1992 to June 2005, a total of 157 months. For the SZSE, the sub period is from February 1996 to June 2005, a total of 113 months.

All major results remain true. According to the descriptive statistics (see Table 6), the market portfolio excess return is insignificant. The value and size premiums are significant. The regression results (Table 7) suggest that: 1) the returns are not correlated with market beta; 2) There exists a significant value effect in the Shanghai stock market. The degree of significance increased from $10 \%$ (the whole period) to $5 \%$ (the sub period); 3 ) No significant size effect was found; 4) the three-factor model produces the highest adjust $\mathrm{R}^{2}$.

In addition, the model works equally effectively for the SSE. A main difference is the noticeable improvement in performance of the model for the SZSE. During the whole period, the model fails and generates high pricing errors. During the sub period, the pricing errors, measured by the intercepts, are all economically smaller and statistically insignificant. The Shenzhen stock market seems to be more sensitive to the exchange rate policy reform and the financial crisis.

A summary of the findings and my conclusions are provided in Section 5.

\section{Concluding Remarks}

In the past 30 years China experienced extraordinary economic growth and has become an increasingly important member of the global economy. One of the critical economic reforms was the introduction and the development of the stock markets. Still young and immature, the Chinese stock markets have grown rapidly and now become the second largest in terms of market capitalization. As any new and emerging market, the stock markets in China exhibit special characteristics. The firms are subject to heavy government regulations and unique tax treatment; the markets are dominated by small retail investors who are primarily interested in short-term profit and speculation; there are ordinary public shares that are tradable and shares not tradable representing state and legal entity ownership; accounting and financial data are short of global norms and lack transparency.

As described in most media, one may easily question the efficiency and the rationality of the Chinese stock pricing mechanism. It is very interesting to explore whether the asset-pricing regularities found in major equity markets and many emerging markets also exist in China. Such investigations are few in the literature. 
The widely accepted and empirically significant risk factors for the cross-sectional expected returns are the market beta, the value premium, and the size premium as in Fama and French (1993). In this paper, the multi-factor asset pricing formula is applied to the Shanghai and Shenzhen listed stocks in the hope to gain more understanding of the pricing mechanism in China.

A main contribution of this work is the construction and the adoption of the benchmark explanatory returns, the value and the size premium, for the Chinese A-share markets. The low correlations among the explanatory variables allow for more accurate and reliable interpretation of the regression results.

The descriptive statistics demonstrate positive market portfolio (A-share index) excess returns over the sample period but contradicting to most equity markets, the reward on the market risk is not significant; reflecting the extremely volatile nature of the Chinese stock markets. There are significant value and size premiums, both statistically and economically.

Applying the Fama-MacBeth two-stage regression methodology, I find that market beta has no explanatory power. There are some evidences of the value effect only for the SSE. No significant size effect was found. Inclusion of the value and the size factor helps increase the adjusted $\mathrm{R}^{2}$. The results are robust when the influences of the exchange rate reform and the recent financial crisis were removed. The model works better in general for the SSE than for the SZSE, regardless of the specifications. There may well be different fundamental forces in the two markets.

In conclusion, the pricing regularities pervasive in most equity markets do not explain the Chinese markets sufficiently well. The specific factors unique to the Chinese stocks are worth further exploration.

\section{References}

Ahlgren, Niklas, Bo Sjo, and Jianhua Zhang. (2009). Panel Cointegration of Chinese A and B Shares. Applied Financial Economics 19, 1859-71.

Banz, Rolf W. (1981). The relationship between return and market value of common stocks. Journal of Financial Economics 9, 3-18.

Barry, C.B., et al. (2002). Robustness of size and value effects in emerging equity markets. 1985-2000, Emerging Markets Review 3, 1-30

Black, F. (1972). Capital market equilibrium with restricted borrowing. Journal of Business 45, 444-455.

Cai, Jinghan, Yuming Li, and Yuehua Qi. (2006). The Day-of-the-Week Effect: New Evidence from the Chinese Stock Market. Chinese Economy 39, 71-88.

Chan, L., Y. Hamao, and J. Lakonishok. (1991). Fundamentals and stock returns in Japan. Journal of Finance 46, 1739-1789.

Chan, K., A. J. Menkveld, and Z. Yang. (2008). Information Asymmetry and Asset Prices: Evidence from the China Foreign Share Discount. Journal of Finance 63, 159-96.

Charles, A. and O. Darné. (2009). The random walk hypothesis for Chinese stock markets: Evidence from variance ratio tests. Economic Systems 33, 117-126.

Chen, G., M. Firth, Y. Xin, and L. Xu. (2008). Control Transfers, Privatization, and Corporate Performance: Efficiency Gains in China's Listed Companies. Journal of Financial and Quantitative Analysis 43, 161-90.

Chen, Gongmeng, Chuck C Y Kwok, and Oliver M Rui. (2001). The Day-of-the-Week Regularity in the Stock Markets of China. Journal of Multinational Financial Management 11, 139-63.

Cheng, Siwei. (2009). An Analysis of China's Stock Market in the First 10 Years. Review of Pacific Basin Financial Markets and Policies 12, 629-653

de Bondt, Gabe J., Tuomas A. Peltonen, and Daniel Santabarbara. (2010). Booms and Busts in China's stock market: Estimates based on Fundamentals. European Central Bank working paper series, No 1190, May.

Drew, M.E., T. Naughton, and M. Veeraraghavan. (2003). Firm size, book-to-market equity and security returns: Evidence from the Shanghai Stock Exchange. Australian Journal of Management 28, 119-139.

Eun, C.S. and Wei Huang. (2007). Asset pricing in China's domestic stock markets: Is there a logic? Pacific-Basin Finance Journal 15, 452-80

Fama, E. and K. French. (1992). The cross-section of expected stock returns. Journal of Finance 47, 427-466

Fama, E. and K. French. (1993). Common risk factors in the returns on stocks and bonds. Journal of Financial Economics 33, 3-56

Fama, E. and K. French. (1998). Value versus growth: the international evidence. Journal of Finance 53, 1975-1999

Fama, E. and J. MacBeth. (1973). Risk, return, and equilibrium: empirical tests. Journal of Political Economy 71, 607-636 
Fan, K., Z. Lu, and S. Wang. (2009). Dynamic Linkages between the China and International Stock Markets. Asia-Pacific Financial Markets 16, 211-30

Fernald, J. G. and J. H. Rogers. (2002). Puzzles in the Chinese stock market. Review of Economics and Statistics 84, 416-432.

Fung, H. G., W. Lee, and W. K. Leung. (2000). Segmentation of the A- and B-share Chinese equity markets. Journal of Financial Research 23, 179-195.

Hung, Jui-Cheng. (2009). Deregulation and Liberalization of the Chinese Stock Market and the Improvement of Market Efficiency. Quarterly Review of Economics and Finance 49, 843-57.

Lai, Yihao, Jen-Ching Tseng. (2010). The Role of Chinese Stock Market in Global Stock Markets: A Safe Haven or a Hedge? International Review of Economics and Finance 19, 211-18.

Lee, Bong-Soo, Oliver Rui, and Wenfeng Wu. (2008). Market Segmentation and Stock Prices Discount in the Chinese Stock Market: Revisiting B-Share Discounts in the Chinese Stock Market. Asia-Pacific Journal of Financial Studies 37, 1-40.

Lim, Kian-Ping and Robert Brooks. (2009). Are Chinese Stock Markets Efficient? Further Evidence from a Battery of Nonlinearity Tests. Applied Financial Economics 19, 147-55.

Lintner, J. (1965). The valuation of risk assets and the selection of risky investments in stock portfolios and capital budgets. Review of Economics and Statistics 47, 13-37.

Liu, X., H. Song, and P. Romilly. (1997). Are Chinese Stock Markets Efficient? A Cointegration and Causality Analysis. Applied Economics Letters 4, 511-15.

Narayan, Paresh Kumar, and Xinwei Zheng. (2010). Market Liquidity Risk Factor and Financial Market Anomalies: Evidence from the Chinese Stock Market. Pacific-Basin Finance Journal 18, 509-20.

Oqunc, A., S. Nippani, and K. Washer. (2009). Seasonality Tests on the Shanghai and Shenzhen Stock Exchanges: An Empirical Analysis. Applied Financial Economics 19, 681-92.

Qi, D., W. Wu, and H. Zhang. (2000). Shareholding structure and corporate performance of partially privatized firms: Evidence from listed Chinese companies. Pacific-Basin Finance Journal 8, 587-610.

Rutledge, Robert W., Z. Zhang, and K. Karim. (2008). Is There a Size Effect in the Pricing of Stocks in the Chinese Stock Markets?: The Case of Bull versus Bear Markets. Asia-Pacific Financial Markets 15, 117-33.

Schuppli, M., and M. Bohl. (2010). Do Foreign Institutional Investors Destabilize China's A-Share Markets? Journal of International Financial Markets, Institutions and Money 20, 36-50.

Shanken, Jay. (1992). On the estimation of beta-pricing models. Review of Financial Studies 5, 1-34.

Sharpe, W. F. (1964). Capital asset prices: a theory of market equilibrium under conditions of risk. Journal of Finance 19, 425-442.

Tunaru, R., F. Fabozzi, and T. Wu. (2006). Chinese Equity Market and the Efficient Frontier. Applied Financial Economics Letters 2, 87-94.

Wang, Yudong, Li Liu, and Rongbao Gu. (2009). Analysis of Efficiency for Shenzhen Stock Market Based on Multifractal Detrended Fluctuation Analysis. International Review of Financial Analysis 18, 271-76.

Xiao, Feng. (2006). Irrational Exuberance and Stock Market Valuations: Evidence from China. Journal of Post Keynesian Economics 29, 285-308.

Zhang and Zhao. (2004). The value differential between class A and B Shares: Country risk in the Chinese stock market. Journal of International Financial Management and Accounting 15, 44-59.

Zhang, Z., W. Sun, and H. Wang. (2008). A New Perspective on Financial Anomalies in Emerging Markets: The Case of China. Applied Financial Economics 18, 1681-95.

\section{Notes}

Note1. The Fama and French sample includes international portfolios from Morgan Stanly Capital International (MSCI) which consists of only large firms and therefore the size premium is not examined. The thirteen major markets are: U.S., Japan, U.K., France, Germany, Italy, Netherlands, Belgium, Switzerland, Sweden, Australia, Hong Kong, and Singapore. The sixteen emerging markets are: Argentina, Brazil, Chile, Colombia, Greece, India, Jordan, Korea, Malaysia, Mexico, Nigeria, Pakistan, Philippines, Taiwan, Venezuela, and Zimbabwe.

Note 2. From the SSE and the SZSE Monthly Market Statistics (May 2010).

Note 3. In February 2006, China's A-share markets are open to qualified foreign institutional investors. 
Note 4. Special thanks to Mr. Zhu from The Taiwan Economic Journal's China Database who generously helped me with data collecting.

Note 5. Similar results can be found in Fama-French (1998), Table VII; there are economically quite significant value and/or size premiums in several emerging markets.

Note 6. On July 21,2005 , after more than a decade of strictly pegging the Renminbi to the U.S. dollar at an exchange rate of 8.28, the People's Bank of China (PBOC) announced a revaluation of the currency and a reform of the exchange rate regime. Under the reform, the PBOC will incorporate a "reference basket" of currencies when choosing its target for the Renminbi. Since then, the RMB has appreciated against the USD by about $20 \%$.

Note 7. The Chinese stock markets were extremely volatile during the period 2005-08. The Shanghai Stock Exchange Composite Index increased more than six fold from 1,012 in 2005 to 6,124 by the end of 2007. It then declined continuously to reach a low of 1,929 on 17 September 2008, or a drop of 70 percent from its peak in less than 10 months.

Table 1. Development of the Chinese Stock Markets

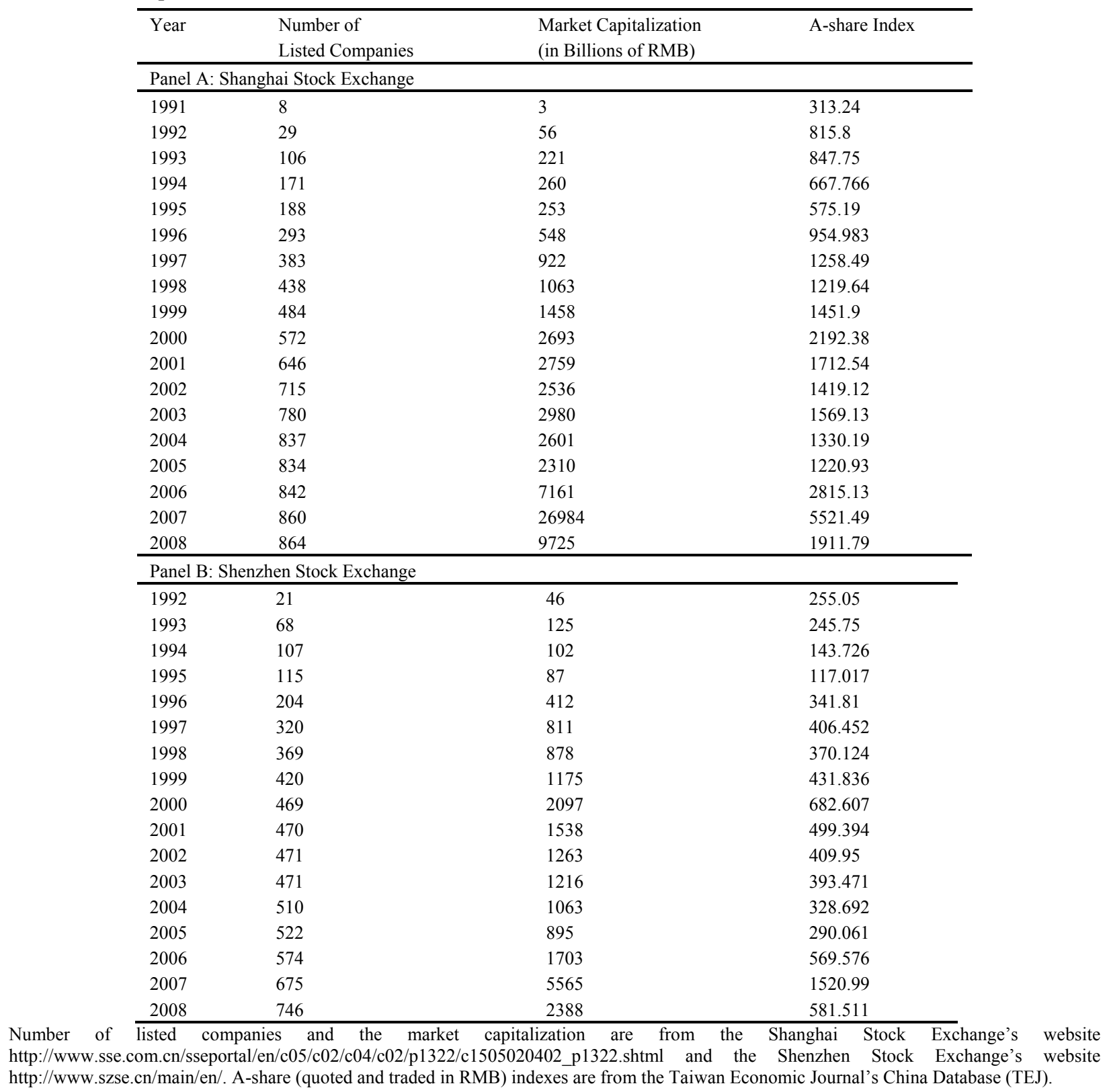


Table 2. Descriptive Statistics of the Explanatory Variables

\begin{tabular}{llll}
\hline & M-F & H-L & S-B \\
\hline Panel A: Shanghai Stock Exchange & & & \\
\hline Max & 89.34 & 33.16 & 33.67 \\
Min & -38.36 & -11.65 & -9.68 \\
Mean & 0.09 & $2.59^{* * *}$ & $2.23^{* * *}$ \\
Std. & 13.26 & 4.29 & 5.05 \\
T-statistic & 0.09 & 8.60 & 6.28 \\
\hline Panel B: Shenzhen Stock Exchange & & & \\
\hline Max & 37.12 & 14.50 & 15.54 \\
Min & -27.37 & -7.31 & -12.06 \\
Mean & 1.10 & $2.13^{* * *}$ & $1.80^{* * *}$ \\
Std. & 10.32 & 3.04 & 4.31 \\
T-statistic & 1.34 & 8.84 & 5.28 \\
\hline
\end{tabular}

$\mathrm{M}$ is the A-share market index return. $\mathrm{F}$ is the three month fixed deposits rate. $\mathrm{H}-\mathrm{L}$ is the value premium (the difference of the average return between companies with high book-to-market ratios and low book-to-market ratios) and S-B is the size premium (the difference of the average return between small firms and big firms). The sample period is from June 1992 to April 2009, a total of 203 months (SSE); from February 1996 to April 2009, a total of 159 months (SZSE). ${ }^{* * *}$ indicates significance at the $1 \%$ level.

Table 3. Correlation Coefficients of the Explanatory Variables

\begin{tabular}{llll}
\hline \multicolumn{1}{l}{ Panel A: Shanghai Stock Exchange } & & \\
\hline & M-F & H-L & S-B \\
M-F & 1 & 0.039 & -0.04 \\
H-L & 0.039 & 1 & 0.66 \\
S-B & -0.04 & 0.66 & 1 \\
\hline Panel B: Shenzhen Stock Exchange & & \\
\hline \multicolumn{5}{r}{} & M-F & H-L & S-B \\
M-F & 1 & 0.17 & 0.034 \\
H-L & 0.17 & 1 & 0.005 \\
S-B & 0.034 & 0.005 & 1 \\
\hline
\end{tabular}

$\mathrm{M}$ is the $\mathrm{A}$-share market index return. $\mathrm{F}$ is the three month fixed deposits rate. $\mathrm{H}$-L is the value premium (the difference of the average return between companies with high book-to-market ratios and low book-to-market ratios) and S-B is the size premium (the difference of the average return between small firms and big firms). The sample period is from June 1992 to April 2009, a total of 203 months (SSE); from February 1996 to April 2009, a total of 159 months (SZSE). 
Table 4. Descriptive Statistics of Betas Estimated from the First-Pass Time-Series Regressions

\begin{tabular}{|c|c|c|c|c|c|c|}
\hline & $\widehat{\beta_{1}}$ & $\widehat{\beta_{2}}$ & $\widehat{\beta_{3}}$ & $\widehat{\beta_{1}}$ & $\widehat{\beta_{2}}$ & $\widehat{\beta_{3}}$ \\
\hline & \multicolumn{2}{|c|}{ Shanghai Stock Exchange } & & \multicolumn{2}{|c|}{ Shenzhen Stock Exchange } & \\
\hline $\operatorname{Max}$ & 1.58 & & & 1.45 & & \\
\hline Min & 0.42 & & & 0.48 & & \\
\hline Mean & 1.01 & & & 1.08 & & \\
\hline Std. & 0.16 & & & 0.15 & & \\
\hline $\operatorname{Max}$ & & 2.03 & & & 1.64 & \\
\hline Min & & -1.71 & & & -1.73 & \\
\hline Mean & & 0.35 & & & 0.09 & \\
\hline Std. & & 0.64 & & & 0.56 & \\
\hline Max & & & 2.72 & & & 2.20 \\
\hline Min & & & -0.95 & & & -1.03 \\
\hline Mean & & & 0.81 & & & 0.62 \\
\hline Std. & & & 0.61 & & & 0.53 \\
\hline Max & 1.57 & 1.84 & & 1.47 & 1.14 & \\
\hline Min & 0.43 & -1.98 & & 0.48 & -1.94 & \\
\hline Mean & 1.01 & 0.28 & & 1.08 & -0.06 & \\
\hline Std. & 0.16 & 0.57 & & 0.15 & 0.51 & \\
\hline Max & 1.56 & & 2.69 & 1.46 & & 2.13 \\
\hline Min & 0.42 & & -0.92 & 0.48 & & -1.16 \\
\hline Mean & 1.03 & & 0.92 & 1.07 & & 0.52 \\
\hline Std. & 0.16 & & 0.60 & 0.14 & & 0.53 \\
\hline Max & & 1.88 & 2.68 & & 1.65 & 2.00 \\
\hline Min & & -2.30 & -0.71 & & -1.26 & -1.02 \\
\hline Mean & & 0.02 & 0.80 & & 0.15 & 0.62 \\
\hline Std. & & 0.65 & 0.63 & & 0.52 & 0.53 \\
\hline Max & 1.56 & 1.39 & 2.68 & 1.45 & 1.21 & 1.91 \\
\hline Min & 0.43 & -2.03 & -0.52 & 0.48 & -1.83 & -1.15 \\
\hline Mean & 1.03 & -0.10 & 0.94 & 1.07 & -0.01 & 0.51 \\
\hline Std. & 0.16 & 0.56 & 0.61 & 0.15 & 0.48 & 0.52 \\
\hline
\end{tabular}

The first-pass time series regression equation is $\mathrm{R}-\mathrm{F}=\alpha+\beta_{1}[\mathrm{M}-\mathrm{F}]+\beta_{2}[\mathrm{H}-\mathrm{L}]+\beta_{3}[\mathrm{~S}-\mathrm{B}]+\varepsilon . \widehat{\beta_{1}}, \widehat{\beta_{2}}$, and $\widehat{\beta_{3}}$ are the estimated coefficients (risk loadings) on the market portfolio excess return M-F, the value premium H-L, and the size premium S-B respectively. The betas are estimated for the 744 companies on the SSE and the 468 companies on the SZSE in sample. The maximum value, minimum value, mean value and standard deviation of the firm betas for various model specifications are reported. 
Table 5. Second-Pass Month-by-Month Cross-Sectional Regression Results (Whole Period)

\begin{tabular}{|c|c|c|c|c|c|}
\hline & $\widehat{\mathrm{a}_{0}}($ Intercept $)$ & $\widehat{\mathrm{a}_{1}}(\mathrm{M}-\mathrm{F})$ & $\widehat{\mathrm{a}_{2}}(\mathrm{H}-\mathrm{L})$ & $\widehat{\mathrm{a}_{3}}(\mathrm{~S}-\mathrm{B})$ & Adj. $R^{2}$ \\
\hline & \multicolumn{5}{|c|}{ Panel A: Shanghai Stock Exchange } \\
\hline $\begin{array}{l}\text { Mean } \\
\text { (T-statistic) }\end{array}$ & $\begin{array}{l}0.62 \\
(0.45)\end{array}$ & $\begin{array}{l}-0.38 \\
(-0.24)\end{array}$ & & & 0.03 \\
\hline $\begin{array}{l}\text { Mean } \\
\text { (T-statistic) }\end{array}$ & $\begin{array}{l}-0.17 \\
(-0.18)\end{array}$ & & $\begin{array}{l}0.70 \\
(1.58)\end{array}$ & & 0.03 \\
\hline $\begin{array}{l}\text { Mean } \\
\text { (T-statistic) }\end{array}$ & $\begin{array}{l}0.06 \\
(0.06)\end{array}$ & & & $\begin{array}{l}0.38 \\
(0.73)\end{array}$ & 0.05 \\
\hline $\begin{array}{l}\text { Mean } \\
\text { (T-statistic) }\end{array}$ & $\begin{array}{l}0.08 \\
(0.11)\end{array}$ & $\begin{array}{l}-0.07 \\
(-0.06)\end{array}$ & $\begin{array}{l}0.71 * \\
(1.73)\end{array}$ & & 0.05 \\
\hline $\begin{array}{l}\text { Mean } \\
\text { (T-statistic) }\end{array}$ & $\begin{array}{l}-0.90 \\
(-0.80)\end{array}$ & $\begin{array}{l}0.92 \\
(0.74)\end{array}$ & & $\begin{array}{l}0.38 \\
(0.74)\end{array}$ & 0.07 \\
\hline $\begin{array}{l}\text { Mean } \\
\text { (T-statistic) }\end{array}$ & $\begin{array}{l}0.09 \\
(0.09)\end{array}$ & & $\begin{array}{l}0.68 \\
(1.60)\end{array}$ & $\begin{array}{l}0.24 \\
(0.52)\end{array}$ & 0.07 \\
\hline \multirow[t]{2}{*}{ (T-statistic) } & $\begin{array}{l}-0.13 \\
(-0.16) \\
\end{array}$ & $\begin{array}{l}0.35 \\
(0.31) \\
\end{array}$ & $\begin{array}{l}0.73^{*} \\
(1.82) \\
\end{array}$ & $\begin{array}{l}0.29 \\
(0.61) \\
\end{array}$ & 0.09 \\
\hline & \multicolumn{5}{|c|}{ Panel B: Shenzhen Stock Exchange } \\
\hline $\begin{array}{l}\text { Mean } \\
\text { (T-statistic) }\end{array}$ & $\begin{array}{l}1.35^{* *} \\
(1.99)\end{array}$ & $\begin{array}{l}-0.40 \\
(-0.36)\end{array}$ & & & 0.03 \\
\hline $\begin{array}{l}\text { Mean } \\
\text { (T-statistic) }\end{array}$ & $\begin{array}{l}0.83 \\
(0.94)\end{array}$ & & $\begin{array}{l}0.37 \\
(1.47)\end{array}$ & & 0.02 \\
\hline $\begin{array}{l}\text { Mean } \\
\text { (T-statistic) }\end{array}$ & $\begin{array}{l}1.33 \\
(1.57)\end{array}$ & & & $\begin{array}{l}-0.66^{*} \\
(-1.77)\end{array}$ & 0.04 \\
\hline $\begin{array}{l}\text { Mean } \\
\text { (T-statistic) }\end{array}$ & $\begin{array}{l}1.18^{*} \\
(1.74)\end{array}$ & $\begin{array}{l}-0.21 \\
(-0.19)\end{array}$ & $\begin{array}{l}0.45 \\
(1.48)\end{array}$ & & 0.05 \\
\hline $\begin{array}{l}\text { Mean } \\
\text { (T-statistic) }\end{array}$ & $\begin{array}{l}1.16^{*} \\
(1.74)\end{array}$ & $\begin{array}{l}0.11 \\
(0.10)\end{array}$ & & $\begin{array}{l}-0.68^{*} \\
(-1.81)\end{array}$ & 0.07 \\
\hline $\begin{array}{l}\text { Mean } \\
\text { (T-statistic) }\end{array}$ & $\begin{array}{l}1.21 \\
(1.47)\end{array}$ & & $\begin{array}{l}0.16 \\
(0.62)\end{array}$ & $\begin{array}{l}-0.58 \\
(-1.53)\end{array}$ & 0.06 \\
\hline $\begin{array}{l}\text { Mean } \\
\text { (T-statistic) }\end{array}$ & $\begin{array}{l}1.13^{*} \\
(1.65)\end{array}$ & $\begin{array}{l}0.11 \\
(0.10)\end{array}$ & $\begin{array}{l}0.19 \\
(0.65)\end{array}$ & $\begin{array}{l}-0.61 \\
(-1.63)\end{array}$ & 0.09 \\
\hline
\end{tabular}

The regression equation is $\mathrm{R}-\mathrm{F}=\mathrm{a}_{0}+\mathrm{a}_{1} \widehat{\beta_{1}}+\mathrm{a}_{2} \widehat{\beta_{2}}+\mathrm{a}_{3} \widehat{\beta_{3}}+\mathrm{e} . \widehat{\beta_{1}}, \widehat{\beta_{2}}$, and $\widehat{\beta_{3}}$ are the estimated risk loadings from the first-pass time series regressions. $\widehat{a_{0}}, \widehat{a_{1}}, \widehat{a_{2}}$, and $\widehat{a_{3}}$ are the estimated intercepts and slopes in the second pass regressions; representing the pricing error, the return on the market portfolio, the value premium, and the size premium respectively. $\mathrm{R}$ is the individual monthly stock return in percent. $\mathrm{F}$ is the three month fixed deposits rate. $\mathrm{M}$ is the A-share market index return. H-L is the value premium (the difference of the average returns between companies with high book-to-market ratios and low book-to-market ratios) and S-B is the size premium (the difference of the average returns between small firms and big firms). The sample period is from June 1992 to April 2009, a total of 203 months (SSE); from February 1996 to April 2009, a total of 159 months (SZSE). Mean is the average of the second-pass month-by-month estimated coefficients. The T-statistics are corrected for the errors-in-variables problem. ** indicates significance at the $5 \%$ level. * indicates significance at the $10 \%$ level.

Table 6. Sub Period Descriptive Statistics of the Explanatory Variables

\begin{tabular}{llll}
\hline \multicolumn{1}{l}{ M-F } & H-L & S-B \\
\hline \multicolumn{2}{l}{ Panel A: Shanghai Stock Exchange } & & \\
\hline Max & 89.34 & 33.16 & 33.67 \\
Min & -38.36 & -11.65 & -8.71 \\
Mean & -0.36 & $2.69^{* * *}$ & $2.34^{* * *}$ \\
Std. & 13.80 & 4.62 & 4.97 \\
T-statistic & -0.33 & 7.29 & 5.88 \\
\hline Panel B: Shenzhen Stock Exchange & & \\
\hline Max & 37.12 & 14.50 & 11.75 \\
Min & -26.75 & -7.31 & -7.24 \\
Mean & 0.58 & $2.02^{* * *}$ & $1.79^{* * *}$ \\
Std. & 9.53 & 3.11 & 3.32 \\
T-statistic & 0.64 & 6.89 & 5.72 \\
\hline
\end{tabular}

To exclude the effect of an exchange rate policy change (July 2005) and recent financial crisis and global recession, a sub period was created. All months after June 2005 were deleted from the original sample. The sub period is from June 1992 to June 2005, a total of 157 months (SSE); from February 1996 to June 2005, a total of 113 months (SZSE). M is the A-share market index return. F is the three month fixed deposits rate. H-L is the value premium (the difference of the average return between companies with high book-to-market ratios and low book-to-market ratios) and $\mathrm{S}-\mathrm{B}$ is the size premium (the difference of the average return between small firms and big firms). $* * *$ indicates significance at the $1 \%$ level. 
Table 7. Sub Period Second-Pass Month-by-Month Cross-Sectional Regression Results

\begin{tabular}{|c|c|c|c|c|c|}
\hline & $\widehat{\mathrm{a}_{0}}($ Intercept $)$ & $\widehat{a_{1}}(M-F)$ & $\widehat{a_{2}}(H-L)$ & $\widehat{\mathrm{a}_{3}}(\mathrm{~S}-\mathrm{B})$ & Adj. $R^{2}$ \\
\hline & \multicolumn{5}{|c|}{ Panel A: Shanghai Stock Exchange } \\
\hline $\begin{array}{l}\text { Mean } \\
\text { (T-statistic) }\end{array}$ & $\begin{array}{l}-0.11 \\
(-0.08)\end{array}$ & $\begin{array}{l}-0.28 \\
(-0.16)\end{array}$ & & & 0.03 \\
\hline $\begin{array}{l}\text { Mean } \\
\text { (T-statistic) }\end{array}$ & $\begin{array}{l}-0.92 \\
(-0.84)\end{array}$ & & $\begin{array}{l}1.06 * * \\
(2.02)\end{array}$ & & 0.04 \\
\hline $\begin{array}{l}\text { Mean } \\
\text { (T-statistic) }\end{array}$ & $\begin{array}{l}-0.60 \\
(-0.54)\end{array}$ & & & $\begin{array}{l}0.56 \\
(1.07)\end{array}$ & 0.06 \\
\hline $\begin{array}{l}\text { Mean } \\
\text { (T-statistic) }\end{array}$ & $\begin{array}{l}-0.24 \\
(-0.30)\end{array}$ & $\begin{array}{l}-0.30 \\
(-0.24)\end{array}$ & $\begin{array}{l}1.21 * * \\
(2.45)\end{array}$ & & 0.07 \\
\hline $\begin{array}{l}\text { Mean } \\
\text { (T-statistic) }\end{array}$ & $\begin{array}{l}-1.07 \\
(-1.04)\end{array}$ & $\begin{array}{l}0.43 \\
(0.32)\end{array}$ & & $\begin{array}{l}0.56 \\
(1.07)\end{array}$ & 0.09 \\
\hline $\begin{array}{l}\text { Mean } \\
\text { (T-statistic) }\end{array}$ & $\begin{array}{l}-0.70 \\
(-0.64)\end{array}$ & & $\begin{array}{l}0.93 * \\
(1.90)\end{array}$ & $\begin{array}{l}0.46 \\
(0.97)\end{array}$ & 0.08 \\
\hline $\begin{array}{l}\text { Mean } \\
\text { (T-statistic) }\end{array}$ & $\begin{array}{l}-0.47 \\
(-0.55) \\
\end{array}$ & $\begin{array}{l}(-0.04) \\
(-0.03) \\
\end{array}$ & $\begin{array}{l}1.03 * * \\
(2.23) \\
\end{array}$ & $\begin{array}{l}0.51 \\
(1.03) \\
\end{array}$ & 0.11 \\
\hline (T-statistic) & \multicolumn{5}{|c|}{ Panel B: Shenzhen Stock Exchange } \\
\hline $\begin{array}{l}\text { Mean } \\
\text { (T-statistic) }\end{array}$ & $\begin{array}{l}0.63 \\
(0.80)\end{array}$ & $\begin{array}{l}-0.32 \\
(-0.25)\end{array}$ & & & 0.04 \\
\hline $\begin{array}{l}\text { Mean } \\
\text { (T-statistic) }\end{array}$ & $\begin{array}{l}0.23 \\
(0.26)\end{array}$ & & $\begin{array}{l}0.40 \\
(1.47)\end{array}$ & & 0.03 \\
\hline $\begin{array}{l}\text { Mean } \\
\text { (T-statistic) }\end{array}$ & $\begin{array}{l}0.65 \\
(0.72)\end{array}$ & & & $\begin{array}{l}-0.58 \\
(-1.69)\end{array}$ & 0.03 \\
\hline $\begin{array}{l}\text { Mean } \\
\text { (T-statistic) }\end{array}$ & $\begin{array}{l}0.38 \\
(0.48)\end{array}$ & $\begin{array}{l}0.00 \\
0.00\end{array}$ & $\begin{array}{l}0.51 \\
(1.40)\end{array}$ & & 0.07 \\
\hline $\begin{array}{l}\text { Mean } \\
\text { (T-statistic) }\end{array}$ & $\begin{array}{l}0.60 \\
(0.79)\end{array}$ & $\begin{array}{l}-0.08 \\
(-0.06)\end{array}$ & & $\begin{array}{l}-0.57 \\
(-1.63)\end{array}$ & 0.07 \\
\hline $\begin{array}{l}\text { Mean } \\
\text { (T-statistic) }\end{array}$ & $\begin{array}{l}0.46 \\
(0.53)\end{array}$ & & $\begin{array}{l}0.27 \\
(0.93)\end{array}$ & $\begin{array}{l}-0.45 \\
(-1.28)\end{array}$ & 0.05 \\
\hline $\begin{array}{l}\text { Mean } \\
\text { (T-statistic) }\end{array}$ & $\begin{array}{l}0.42 \\
(0.55)\end{array}$ & $\begin{array}{l}0.10 \\
(0.08)\end{array}$ & $\begin{array}{l}0.38 \\
(1.05)\end{array}$ & $\begin{array}{l}-0.44 \\
(-1.25)\end{array}$ & 0.10 \\
\hline
\end{tabular}

To exclude the effect of an exchange rate policy change (July 2005) and recent financial crisis and global recession, a sub period was created. All months after June 2005 were deleted from the original sample. The sub period is from June 1992 to June 2005, a total of 157 months (SSE); from February 1996 to June 2005, a total of 113 months (SZSE). The regression equation is $R-F=a_{0}+a_{1} \widehat{\beta_{1}}+a_{2} \widehat{\beta_{2}}+a_{3} \widehat{\beta_{3}}+e$. $\widehat{\beta_{1}}, \widehat{\beta_{2}}$, and $\widehat{\beta_{3}}$ are the estimated risk loadings from the first-pass time series regressions. $\widehat{a_{0}}, \widehat{a_{1}}, \widehat{a_{2}}$, and $\widehat{a_{3}}$ are the estimated intercepts and slopes in the second pass regressions; representing the pricing error, the return on the market portfolio, the value premium, and the size premium respectively. $\mathrm{R}$ is the individual monthly stock return in percent. $\mathrm{F}$ is the three month fixed deposits rate. $\mathrm{M}$ is the A-share market index return. $\mathrm{H}-\mathrm{L}$ is the value premium (the difference of the average returns between companies with high book-to-market ratios and low book-to-market ratios) and S-B is the size premium (the difference of the average returns between small firms and big firms). Mean is the average of the second-pass month-by-month estimated coefficients. The T-statistics are corrected for the errors-in-variables problem. ** indicates significance at the $5 \%$ level. * indicates significance at the $10 \%$ level. 